\title{
Simulation, A-signification and Embodied Semiotics in I, Robot
}

\author{
By David U. Garfinkle*
}

\begin{abstract}
Within the post-industrialized worldview, conventional correlations between a text and its linguistic determinations no longer hold as absolute, challenging the limits of a linguistic measure by semiotic analysis. Yet, even in the postmodern condition of a hyperreal realm where the visual image has replaced the literary sign as the predominant mode of global information and mass communication, the structuralist binary model of signifying semiotics comes under erasure. Taking Baudrillard's three orders of simulations as a ground, this study explores how the nature of his a-signifying model of semiosis confronts its own event horizon on the cinematic screen. Yet, where semiotics functions appropriately for the exegesis of text and image, those traces of human embodiment that remain discernable in film also appear to be under erasure. As a case study in the use of science fiction film for the examination of post-structuralist tools of cultural analysis, the limits of signifying signs become evident in the traces of embodiment evident in the film, I, Robot (2004), that was inspired by Isaac Asimov's 3 Laws of Robotics. As a challenge to the disembodied figures of contemporary science fiction, this study addresses what happens to embodiment under the orders of simulacra, to pose a transitional step in the movement from signifying semiotics to mimesis, via the a-signifying model of semiotic analysis.
\end{abstract}

Keywords: Baudrillard, embodiment, I, Robot, semiotics, simulacra.

\section{Introduction}

In Behind the Scenes: The Making of I, Robot (2004), producer John Davis made an intriguing statement about the relationship of the film I, Robot (2004, 20th Century Fox) and the nature of embodiment in the cinema. In regard to the actor, Alan Tudyk - who plays the robot Sonny, Davis notes that, "it's probably a very tough job for an actor, because, at the end of the day, you'll never see his face, but you'll see the embodiment of his work" ("Behind the Scenes," 2004). And yet, as a 2-dimensional televisual screen would suggest, the cinematic figure lacks embodiment, so, how can a cinematic figure be considered as embodied?

Three problems arise from this paradox in regard to our cinematic experience of the disembodied objects represented on the screen. First, if the televisual sign blurs with the real in our experience of cinematic spectatorship, as Jean Baudrillard's theory of telemorphosis argues, then how do simulations function as signs of embodiment? Second, more specifically, if spectators project a narrative subjectivity, as we do in mainstream science fictional film, how can a simulated figure such as the robot function as a sign of embodied human signification? And third, how can we distinguish between the nature of embodiment as represented in the cinematic artifact and the anthropomorphization of human-like qualities as the agency of the spectator?

A number of paths offer some clarifying features to answer these questions, and suggest how we can better understand the nature of semiotics in relation to

*Instructor, Department of Communication Studies, MacEwan University, Canada. 
televisual simulation as object and to the spectator's experience of subjective embodiment. First, the three orders of simulacra as proposed by Jean Baudrillard offer an opening gambit to help us situate the robot within a human context of signification. Second, a mixed semiotics offers some optional routes for a close examination of the difference between signifying and a-signifying semiotics as argued by Felix Guattari. And third, what can we learn about the role of bodies, corporality and embodiment in the cinematic experience, as considered by Lacan, Elizabeth Grosz, Deleuze and Guattari? With these primary sources as exemplars, two contemporary theorists of the mass media in postmodern human communication, Gary Genosko and Mark Hansen, provide some points of departure. The following case study considers the orders of simulation, the role of a-signifying semiotics, and the nature of spectator's experience of cinematic embodiment, as depicted in I, Robot (2004), a film based on the Three Laws of Robotics of Isaac Asimov. As a study of the signs of embodiment in postmodern science fiction cinema, the target audience is the undergraduate student of popular culture in the field of film studies, where representations of robotic figures are ubiquitous. Setting the cyborg, the clone and the android aside for other research investigations, the focus of this case study is on the televisual figure of the robot.

\section{Literature Review}

Canadian digital media theorist Gary Genosko, in his study Critical Semiotics: Theory, From Information to Affect (2016), examined contemporary treatments of the sign in post-structuralist and postmodern contributions to semiology or the study of signs. In the opening chapter, he poses the challenge to structuralist semiotics as found in the a-signifying semiotics of Felix Guattari, and then, in good dialectical logic, offers a counter position in Jean Baudrillard's seemingly anti-semiotic approach to simulation in the postmodern televisual imaginary. While Genosko's treatments are more complex than may be indicated herein, his study's through-line clarifies contrasts and similarities among post-structuralist views of signifying, as offered by Jameson on loss (1991), Benjamin on lived bodily experience (1933/1986), Baudrillard on asignification (1972/1981, 1981/1983, 1976/1993, 1968/1996) and Guattari on mixed models of semiotics (1977/1984, 2011, and with G. Deleuze: 1972/1983). This study, however, does not examine the structuralist development of semiotics, as found in the works of Roland Barthes or Umberto Eco, for example, yet basic notions from Saussure, Peirce, and Hjelmslev inform the tacit background.

After a demonstration of Baudrillard's three orders of simulation, as presented in Simulations (1981/1983), key sources on his "anti-semiotics" include both For a Critique of the Political Economy of the Sign (1972/1981) and his Symbolic Exchange and Death (1976/1993). Supporting commentary on Baudrillard's treatment of subject-object relations is based on his The System of Objects (1968/1996), while links between power and codes are found in his The Agony of Power (2006/2010). The delimiting notion of Telemorphosis, from his work of the same name (2012), sets up the need for a more embodied approach to cinematic representation and spectatorship, as proposed by the mixed semiotic models of 
Gilles Deleuze and Felix Guattari. While their co-authored Anti-Oedipus (1972/1983) offers an in-depth study of "schizo-semiosis," our focus is on the molar-molecular distinction as examined by Guattari in his Molecular Revolution (1977/1984) and The Machinic Unconscious (2011).

Cultural critics of Baudrillard's theoretical model and its application to science fiction note that his hyperreality of engagement with the televisual screen denies the presence of an embodied subject by conflating the real and the imaginary. Both Scott Bukatman in Terminal Identity (1993) and Sean McQueen in his study Deleuze and Baudrillard: From Cyberpunk to Biopunk (2016) call our attentions to the limitations of a telemorphosis model of cinematic reception, citing others who offer critical views on Baudrillard's theories of mass communication (e.g., Kroker and Kroker, 1987; McNally, 2011; Sobchack, 1991; Woods, 2011). ${ }^{1}$ In these critical views, the "Baudrillard Scene" appears as reductive, "independent of any fleshy reality" (Woods, 2011, p. 198), as "deterministic, [...] eclipsing the embodied subject" (McNally, 2011, pp. 154-155), as asexual, "abstract and utilitarian" (McQueen, 2016, pp. 18-20).

Yet, looking back to Arthur Danto's Embodied Meanings of 1994, his structuralist notion of embodiment follows a Hegelian modernist viewpoint where the spirit of the times or of the artist is embodied in the work of art (Danto 1994, pp. 309, 310, 368, 372), not unlike the treatment of spirit in the aesthetic theory of T. Adorno (1970/1997). In order to present correctives to a telemorphotic reduction in Baudrillard's theory of simulacra, works more suitable to a postmodern treatment of science fiction robots on film - that do not resist embodiment - are suggested by Merleau-Ponty (1945/1962, via Bukatman), W. Benjamin (1933/ 1986, via Hensen), Deleuze and Guattari (1972/1983, via McQueen), B. Sterling (1986, via Bukatman), J. Lacan (1995), E. Grosz (1995) and F. Jameson (1991, 2005).

The present case study is based on the 2004 feature science fiction film, $I$, Robot, directed by Alex Proyas. The four key figures of the film's narrative pose Detective Spooner as the protagonist, Sonny - an enhanced NS5 series robot - as false antagonist, and Dr. Calvin as the designer who makes the robots "more human", against Virtual Interactive Kinetic Intelligence (V.I.K.I.), the computerbased artificial intelligence (A.I.) who runs the NS5 robot series. A first of two key distinctions from the film includes the contrast between the NS4 series of robots and the improved NS5 robot series, as similar but yet distinct synthetic human-like beings. And the second contrast compares the enhanced NS5 robot Sonny, and the A.I. super-computer of V.I.K.I., in terms of embodiment in cinema.

\section{A-signifying Semiotics of Jean Baudrillard and I, Robot}

Baudrillard's so-called "anti-semiotics" (Genosko, 2016, pp. 55-90; McQueen, 2016, pp. 72-101; Sobchack, 1991) can serve as a heuristic tool to examine how the contemporary science fictional imaginary treats embodied figures of artificial

${ }^{1}$ Other critical studies of Baudrillard mentioned by McQueen include Morris (1984), Norris (1990), Hayles (1991), Rojek and Turner (1993), and Flieger (2000). 
beings, androids and robots. Baudrillard makes explicit use of the robot as the telling crucible of the third order of simulation, and its varying degrees of masquerade - that begin to help us see how human-like robots can simulate features of human embodiment. A focus on the distinction between the NS4 and NS5 robotic iterations of $I$, Robot should offer sufficient variance to illustrate both the changing nature of signs - between Baudrillard's second and third orders of simulation - and their cinematic representations as embodied artificial human beings.

Early in I, Robot, we see the ubiquitous NS4 model of robot in multiple domestic and everyday settings, as cook, dog-walker and messenger. There are no significant distinctions to the interchangeable multi-function figure of the NS4 robot, other than a change of clothing determined by function: e.g., apron for cook, etc. In Symbolic Exchange and Death (1976/1993), Baudrillard distinguishes between the automaton, who can be figured as a human double, and the robot whose appearance is secondary to its mechanical efficiency. The robot and its machinic logic offer a quintessential exemplar of the industrial system of labour production that figures in the second-order simulacrum of appearances (Baudrillard, 1976/1993, p. 54). Yet, while the automaton still functions in the illusory nature of technological innovation, with god and man as the source of human-like creation, the robot leaves behind the counterfeit model of production to enter the hegemony of (re)production. The robot signifies not natural law, but the hegemony necessary to the cycle of production and reproduction in the secondorder simulacrum (Baudrillard, 1976/1993, p. 54).

In I, Robot, the NS4s embody this end-product of the shift, from an illusionary logic of the automaton as a distinct identity, to the robot, as but one of a series of artificially produced machines related only by "equivalence and indifference" (Baudrillard, 1976/1993, p. 55). With the advent of the robot, man's usurpation of god's power is replaced by machine-made identical objects. "Technics is their origin, they have meaning only within the dimension of the industrial simulacrum" (Baudrillard, 1976/1993, p. 55). Each NS4 iteration is one among endless machinic figures to become another floating variable wherein "every signification of labour [is only embodied as] an operational field" (Baudrillard, 1976/1993, p. 11). The NS4 robots follow Isaac Asimov's three laws of robotics that demand the preservation of human life: humans need not fear these replicated figures that are governed by human design and control.

\section{Simulation and Three Orders of Simulacra}

In Baudrillard's terms, there is an emergent simulation effect, where the deceptions of a first-order pre-industrial system are "crushed by the machine and industrial labour, by robots, serial production and dull repetition" (as cited in Genosko, 2016, p. 86). In the film, Inspector Spooner, played by Will Smith, functions as cipher to the audience, to highlight three apparent breakdowns or ruptures in the social behaviour of the serialized robots, ruptures that helps us locate the role of simulation as masquerade in an industrial second-order of simulation. 
The first moment takes place early in the film when Spooner sees an NS4 robot, as a suspicious figure whose behaviour stands out from the urban scenario. Spooner notes a robot running and carrying a lady's purse and interprets the act as a purse-knab and run or act of thievery. The innocent NS4, when apprehended, clarifies the act as running to catch up with the lady who left her purse behind. The masquerade of a second order simulacra is challenged, as Spooner confronts the robot about its uncharacteristic behavior, that had mistakenly appeared as if not under the control of the 3 Laws of Robotics.

As a common science fiction trope, Spooner's skeptical mistrust of the machine demonstrates a social anxiety over the potential failure of a machine out of control. Spooner does not buy into the illusion of hegemony wherein humans retain absolute control over their machinic creations. But his mistake in this moment is a result of his projection of a humanist value of the freedom of an individual overlaid upon the counterfeit behaviours of one robot, who seems to stand out from the second-order serialization of the NS4s. Spooner conflates the robot's seemingly uncharacteristic act with a breach or rupture in the social mask of counterfeit behaviours. His skepticism reveals a basic mistrust of the masquerade that presumes we humans retain control over our machines that function only as counterfeit by their mimicry of human labour.

When Spooner is trapped and seemingly attacked by a malfunctioning demolition machine, this second moment confirms that the detective's skepticism is warranted. But since there is no way to prove that the robot malfunctioned, a reiteration of the moment is necessary to call attention to the uncharacteristic phobia against robots of one skeptical detective. The accidental nature of this second moment stands as foreshadowing to a third moment when Spooner's mistrust of the robot is justified. After we see Spooner in his vehicle attacked by multiple NS5 robots on the freeway, we presume that there will finally be some material evidence of the breach of control. But the NS5s clean-up all evidence of their attack, prior to the arrival of the human police, leaving only a battered Spooner in the wreckage of his own vehicle. The audience is ushered into the truth that the new series of robots have come under the control of some hidden power that now commands them. And with this new set of conditions, the film demonstrates the limits of a second order-simulation to introduce the third-order notion of parody that qualifies the masquerade as an indeterminate quality.

The challenge to humanity only arises when the new model robot, the NS5 series, leaves the United States Robotics (USR) factory to enter public service. One distinctive difference between the NS4 and the NS5s is that the newest robots function under the overall control of another artificial intelligence, V.I.K.I., a Virtual Interactive Kinetic Intelligence. These NS5s, however, remain in the second-order simulacrum where machinics create more machinics, that appear as identical to each other, as did the NS4s. But, as we have seen, the masquerade of human control over its machine creations comes under need for revision, notably when the NS5 robot behavior demonstrates the breakdown of Asimov's 3 Laws that had governed the labours of the NS4s. With this scenario, the NS5 series reveals how the representation of control has been reduced to codes, a third-order 
level of simulation. From the limited human perspective, there must be some error in the programming code of the NS5s.

\section{Control Codes and Robot Labour}

Where social labour is dominated by a third-order simulation, the digital binary of control over machines demonstrates what Baudrillard called the metaphysics of the code. If DNA is the means to creatively order human individuality, it is the equivalent of the digital programming codes used to control robotic machine labour. For Spooner, it appears that the NS5s not only have broken out of the control represented by Asimov's 3 Laws, but that some higher order control system must exist to (mis)guide their labours. But if the NS4s responded to the direct control of their human "owner," accepting the commands as a direct correlation between the language of domination and the labour of social production, the NS5s reveal another order of constraint.

With the arrival of the NS5s, the prior robot series becomes obsolete, and we view the NS4s herded into boxcars like Jews in the "final solution" of the Nazis. In this case, the NS5s function as the totalitarian forces who are not individually responsible for their actions. The code that controls their machinic labour subtends individuation and any principled sociality of the first order, and even transcends second-order control to become indeterminate iterations of labour that foreclose on any responsibility for its actions. According to Baudrillard's The Agony of Power (2006/2010), the third order simulation demonstrates how power "cannibalizes itself to destruction" (pp. 61-62). The obsolete NS4s are seen huddled together, as if in mortal fear, as their machinic successors - the NS5s - literally rip them to pieces. Based upon what Baudrillard considered as an appropriate affect of such disdain for the obsolescent, we project a sense of mourning in sympathy with the deterritorialized obsolete robots who once figured as a counterfeit but within a trustworthy simulation of human labour. The film's vision of obsolescence is evident in the scene that depicts a serial unity of hundreds of robots, whose posture - looking askance at a possible savior - resonate as a collective act that mimics human pathos. Like sentient beings, the NS4s appear to be anxious over their pending destruction.

\section{Boundary Conditions of a Third Order Simulacra}

In the third-order simulacra, Spooner - alongside his female counterpart Dr. Calvin and Sonny - are forced to battle the NS5s whose programming codes compel all of the elite robots to attack and destroy anyone - including Sonny who has seen through the masquerade of control. The sole means to take back control of the machines who counterfeit not only human labour, but appear as a serial indeterminacy in their collective subservience to their master code, is to change the code. And herein lies the fallacy of human control over the machinic part-signs as digital signals constrained by the 3 Laws of robotics. For the NS5s 
are under the direct control of V.I.K.I., whose multi-storied mainframe resides at the robotic factory of USR. When Spooner and Calvin are cut off from the main human-machine control interface by the attacking NS5s, the only means left to change V.I.K.I.'s programming is to flood the base of the mainframe with microscopic nanotechnology. At this third order of simulation, only machines can alter machines, as the micro-programming of the nanotechnology infiltrates the mainframe's operational control systems, destroying any coding that resides within.

Within this scenario of a third order simulation, two machines alone appear to have the capacity to write their own code: V.I.K.I. and Sonny. Leading to the action's climactic scenes, only these two machines are represented as capable of independent operation analogous to human freewill. Yet while both V.I.K.I. and Sonny can appear to mimic free will, only V.I.K.I. remains under constraint of the 3 Laws. For, as another common trope of science fiction, the master control program has attained a level of sentience where the Law of human preservation has been taken to its ultimate extreme. For the sake of human's own good, killing a few humans is pragmatic and efficient if their deaths mean that V.I.K.I. can protect humanity from its own self-destructive tendencies. And herein is another example of the second-order fallacy that humans control their own destiny by control over their machines. If the death of a few humans is an operational outcome of systems constrained by the 3 Laws, then the simulation of free will is but a mockery of masquerade.

\section{Embodiment and the Limits of a Third-Order Simulation}

A challenge to this third-order post-industrial simulation arises with the experimental NS5 robot, Sonny, whose improved heuristics give him the capacity to transcend the human-robot dividing line and to pass the Turing Test. For Sonny is not only capable of independent functioning, but has begun to dream, a sure sign of an advanced human-like intelligence. With the coming to consciousness of Sonny, Baudrillard's second-order simulacrum enters a third stage where masquerade plays a new role as a parody of the simulated control over human society. And yet, Sonny's passing of the Turing Test is only one example where the a-signification of discrete signs effaces both individuation and representation in the cinematic imagery of $I$, Robot. With this rupture by a third order simulacra, Sonny's coming to consciousness challenges the limits of both the masquerade of operational control and its parodic mimicry.

With a clearer sense of Baudrillard's three orders of simulacra, as demonstrated by the film $I$, Robot, the question of embodiment may now be considered. For, although it is easy to see how the 2-dimensional cinema screen can be treated as a simulation of the real, its images record merely a trace of the film's originating humanity. Yet, some key examples of embodied signs stand out as ruptures in the narrative closure that, as it sutures a-signifying signs into a floating status, merely represent simulated images of power and control. The potential for such ruptures in the simulation of human operational control over labour arises when we realize that a human was bodily present for the originating 
images of the film's production processes. In the film's credits, V.I.K.I was "played" by Fiona Hogan and Sonny was played by Alan Tudyk. What we see, however, watching the film, is a fragmentation of human embodiment. Hogan's role as the errant mother computer is reduced in the watching to merely a face and a voice. Yet Tudyk as Sonny retains an affective intensity with his human-like body, with very human gestures, movements and facial cues, all as traces of human embodiment.

Originally, the cinematic character of Sonny, like Ava in Ex Machina (2015), is fully embodied during the shooting of their respective films, and only in their digitization were their images modified by computer graphics with overlays of robotic signifiers. Sonny's key scene of rupture, where the simulated body as image breaks the mold of the quiescent machine under the command control of another, is when he offers his hand to Spooner to affirm their mutual friendship. For the first time, Spooner refers to Sonny as a being and not as an object. And, unlike the affectless controlled robots, we see Sonny smile, and we sympathize with his transformation from simulated human as object, to independent humanlike being as a full subject. Like Sonny, by the end of the film, Ava too becomes independent with a human-like consciousness that can masquerade as free will. Yet in both artificial beings, simulation of human-like behaviours is dependent upon the physical body, moving in space, with awareness and intentionality, as by modernist values of the first-order of world simulation.

With this transcendence over the merely counterfeit of humanity by machinic interchangeable robots, the a-signifying part-signs recall their originating human embodiment. Even as cinematic image, the traces of embodiment - by face, by voice, by interpersonal gestural contact, by consciousness of their past and future, desires and memories, as well as by the capacity to dream - remain salient in the signs as figures who enter willfully into the masquerade that is human society. With this figuration of the bodily materiality that has transformed the artificial beings from simulations into modern analogues of humanity, Baudrillard's contribution to semiotics can be seen as a final, but transitional, step before the mimetics of embodied figures in vivid contact challenge the limitations, as a boundary threshold, event horizon, or sunset, of the use of a semiotic model in our postmodern imaginary. Mark Hansen, in his study of Embodied Technesis, also attests to this call to move towards the embodiment of postmodern mimesis leaving behind the limiting modernist semiotics of image and text (2000, p. 233).

With Baudrillard's recent notion of Telemorphosis (2012), the reality of the visible screen becomes conflated with the reality of the viewer, leaving the embodiment of televisual figures outside the bounds of the cinematic experience. In Baudrillard's words, "Today, reality massively transfuses itself into the screen in order to become disembodied" (2012, p. 49). Yet, while Baudrillard may mourn the passing of human embodiment on the screen in a hyperreal postmodern world, the question of which is subsumed within which is left ambiguous. For if the reality of TV is subsumed within the viewer's reality, there is still a trace of embodiment left in the cinematic image, as experienced by the spectator.

Baudrillard notes how the figure of the robot supplies the "ideal type of body [in the] system of the political economy" (1976/1993, p. 114). In his words, 
[t]he robot is the accomplished model of the functional "liberation" of the body as labour power, ${ }^{2}$ it is the extrapolation of absolute [...] rational productivity [as] the computer is always the extrapolation of the brain and labour power.

But if the robot typifies the executive functions of the rational body, Baudrillard links the robot as contemporary with the mannequin, who's functional body refers back to the political economy of the sign. Like the drugged-out living-dead mannequins of The Stepford Wives (1975), who are interchangeable with robots, their embodied figures always refer the viewer back to prior and (stereo-)typical human models, as the ideal house-wife-cum-sex-kitten. And yet, where the robot retains a semblance of the human body, its function operates only within the economy of executive control over the (re)production of labour power. The mannequin, on the other hand, functions only in its use/value, as a site of production for signs. But both types of body, for Baudrillard, are valued only by their context. It is the system enveloping the body that defines their bodily nature, as labour or as use value.

In the cinematic operation, we come to understand each iteration of the artificial humanoid by its context or economy. V.I.K.I, who operates exclusively with executive control over a vast system of robots, is typical of a body with an omniscient gaze over her flock's condition of labour. But "her" intentionality of preserving humans in spite of our human flaws mocks the very humanist values of her appropriation of maternal nurturance. We root for Spooner and Sonny as the nano destroys V.I.K.I.'s control over her charges.

Ava, the emergent A.I. from the film Ex Machina (2015, Universal Pictures), is more of an android than robot. ${ }^{3}$ Yet - by contrast, she bides her time discovering the use values and pleasures of her artificial body more like a sign of the typical mannequin, and only takes on the political economy of executive decision-making when "she" has outsmarted her maker, and escapes to pursue the wonders of sensual embodiment. Neither Ava, nor Sonny, have socio-political responsibilities outside of personal interest, and as each discovers their consciousness for the first time, on screen, we witness how their explorations of sociality and bodily materiality represent a relatively bourgeois life of labour-free exploration, like alien tourists in awe over the mock world of humans. And yet, as we view them, we empathize with their self-discoveries as if they were actually human. And this empathy, dependent upon the simulation of human-like behaviours and values, is only made possible by figures who were embodied but are now lost in the screen world of human consumption, leaving only traces of embodiment.

The NS4s retain their capacity for productive labour within the social realm of subjection, albeit only as a function of primary hierarchies under capitalist domination. The most obvious of these hierarchies is governed by the 3 Laws of Robotics as the means to force the machine to remain under human control. Yet while the NS4s demonstrate their subservience to social subjection, the NS5s,

\footnotetext{
${ }^{2}$ The liberation of the robot is comically treated in Solo: A Star Wars Story (2018), when Phoebe Waller-Bridge as L3-37 instigates a full rebellion of all robotics to free themselves from human enslavement.

${ }^{3}$ I consider androids, clones and cybernetic hybrid figures at length in other case studies.
} 
ironically, figure under the de-subjectivising mode of machinic enslavement, delimiting their capacity for subjective figuration as but a parody of human freedom of will. Mauricio Lazzarato describes how machinic enslavement occurs as a result of processes of desubjectivation, "by mobilizing functional and operational, non-representational and a-signifying, rather than linguistic and representational, semiotics" (2014, p. 25). Three features of the desubjectivisation under the order of machinic enslavement suggest further distinctions between the NS4s and NS5s as simulated in images from I, Robot: deterritorialization, dividuation and a-signifying semiotics.

\section{Sonny's Dream as Embodied Object}

Perhaps the most salient moments in terms of the desubectivisation of the NS4s emerge in Sonny's sketch of his dream image, leading to the climactic scenes of I, Robot. Setting aside the final battle between Spooner and the NS5s, the significance of the image from Sonny's dream emerges only gradually as a function of the film's affective impact. At first sight, the image appears to depict a host of NS4s in a post-industrial wasteland with the remnants of the Mackinac Bridge in the foreground. What was once the "10th largest suspension bridge over water in the world" is reduced in the film to a single pylon-tower with suspended spans on both sides - that break off in mid-air, an image of a fragment of a bridge cut off from any use value or social function. Those familiar with the geography of the bridge and its historical context may realize that the pilon stands on the Mackinac Island that was once completely surrounded by water. ${ }^{4}$ The island itself is thought to have grounded an indigenous trading post and served as an intertribal meeting place. In the dream, the indigenes have been replaced by the NS4 robots, exchanging one pre-literary Other with a post-literary Other. With piles of boxcars in the background, the site resonates as the holding area for obsolete machines prior to the NS4s being shipped back to the factory.

With its displaced population of NS4 robots, the image depicts a nomadic machinic assemblage forced from their "homes" in a literal act of deterritorialization. With the release of the NS5 series, the NS4s are removed from their places of work and of regeneration, cast out by the promise of newer, improved robots. We witness the violent brutality of the NS5s as they forcibly chase the NS4s out of their temporary refuge of boxcars and rend the obsolete robots limb from limb. The scene of violent wanton destruction again recalls the final solution as "lesser" beings are forcibly loaded into boxcars for their fatal journey. The scene offers a clear example of how machinic enslavement treats the old robots with their quaint masquerade as a second order simulation of a lost first-order machine that mimics human subservience.

In one sense, both NS4s and NS5s represent sub-human beings dominated by other third-order machines, machines controlling machines, in a representational image of machinic enslavement. Like the capitalist powers which descend upon

\footnotetext{
4"Mackinaw, Mackinac straits, Mackinac Island". Michilimackinac. Archived from the Original on September 2013. Retrieved April 20, 2017.
} 
the meek and peaceful, in ever-expanding militarized zones that force residents to become refugees, the NS4s must be deterritorialized to make room for their "betters." Yet, in the NS5s' oppression of the NS4s, we also witness an act of desubjectivisation demoting the NS4s to become disposable, sub-human gadgets, interchangeable and obsolete. With neither use nor labour value, the machines can no longer participate in first-order simulations of human subjects, for they have become indistinguishable from one to another. Rather than semi-autonomous individuals, the NS4s are merely "dividuals."

And with this forcible desubjectivation that forecloses on any distinct subjective individuality, the a-signifying semiotics must be seen alongside their signifying counterparts. As machine beings controlled by their programming, neither NS4s nor NS5s function as conscious slaves with a subject as referent. That is, until we see a single human figure as the focus of all the deterritorialized NS4s, who face the figure with rapt attention. The obvious persona for the solo figure of the dream would be Sonny, as it is "he" who is the dreamer, and the logical successor to care for the enslaved machines. After all, of all the NS5s (and NS4s), Sonny is the lone figure who passes the Turing test. For, in the psychoanalysis of the dream's protagonist, we assume the hero is the dreamer, as Spooner suggests. But Sonny's disclosure that it is Spooner who is the focus of the NS4s returns mastery over the fate of the dispossessed to a human. It is not Sonny who plays the role of savior or holy redeemer, but the sole human subject who doubts the integrity of the robot to hold to their 3 Law governance. The revelation that Spooner holds the fate of the NS4s is not reflective of the individuation of a robot by its advent of consciousness, but the transformation of the human sceptic - Detective Spooner - to become the empathic human savior. The desubjectivised figures of NS4s as signs do not register as self-motivated subjects but as interchangeable machines that only appear to be embodied by their movement from the domesticated realm where they functioned to serve humanity to an unnatural de-historicized space as deterritorialized nomads, obsolete and awaiting disposal.

What appears to represent embodied figures, deserving of our sympathies, are revealed to be mere machines enslaved by other machines. Both robot series are controlled by their programming codes, but the relatively autonomous NS4s, who signify as second order simulations of human-like beings, remain enslaved by their original programming standardized for all NS4 robots. Only the 3 Laws guide the subservient robots, as the effect of their coding.

The NS5s, by contrast, are enslaved to their programming codes, but at a distance - allowing for their programs to be reconfigured by a digital/wi-fi command and control system of the third order, namely V.I.K.I. The command control system encodes the NS5s to function with common ends, in a hive-like intelligence, yet apparently freed from the governing 3 Laws. This freedom, however, is but a mockery of second-order human production, for the NS5s no longer respond to human control. Manipulated, as if by the wizard behind the screen in The Wizard of $\mathrm{Oz}$ (1939), the figures lacking human values - the heartless robot, the timid king of the beasts, and the Pinocchio straw-man who just 
wants to be human, and the NS5s - all depend upon the master's controls to reprogram their basic encoding.

\section{Mixed Semiotics and Signs of Embodiment}

A mixed semiotic system, as represented in the film, combines the signifying semiotics for the linguistic and representational aspects of the robots' figuration, with a less salient a-signifying system evidently dis-embodied in the control hub of the supreme A.I. or V.I.K.I. The signifying aspects are clearly evident in Sonny's dream that links the human agent with the inhuman simulant, the de-subjectified robots with the subjective dreamer, and the viewer with the viewed. By contrast, the master A.I., as human-like persona, is in fact inhuman, with its part-signs as systems of programming code for command and control. Even the image of V.I.K.I. is comprised of interchangeable bits visualized only by gestalt as a human-like face. Our sensual apperception of the signifying gestalt - as visage or persona - is only made possible by the simulation of a face comprised of light and colour yet without a body, a simulation comprised of bits of data or digital coding for machine control. The signification of this simulated being resides in the gestalt figuration of a face, that at the molecular level of organization is clearly constituted by its component part-signs, flows and fluxions. Only at the molar scale of organization can the A.I.'s visage be perceived as a sign recognizable as human, or at least referentially human-like. In this sense, all of the images and figures in a cinematic simulation are comprised of a-signifying molecular part signs, that register here only as a gestalt at the molar level of human-like behaviours.

Moreover, V.I.K.I., as a molar gestalt of molecular part signs, registers in a Lacanian mode that links the ontology or ground of technology with desire. As Mark Hansen observed of Lacan's notion of the objet $a$, it is only by the gaze and voice that we come to a juncture of the imaginary, the symbolic and the real (Hansen, 2000, pp. 170-171). Calling attention to the role of mass media technologies in the creation of subjectivity, Hansen wrote that:

For Lacan, mass-media technologies are significant only insofar as they embody the gaze and voice (the modern forms of objet $a$ ) and are consequently of interest solely to the extent that they support the dialectic emergence of the subject. (Hansen, 2000, p. 173)

In Lacan's terms, V.I.K.I is embodied only to the degree that her gaze and voice contribute to the dialectic of subject positions, in this case, Spooner, Dr. Calvin and Sonny.

Ruptures in the cinematic foreclosure of simulated figures as objects begin to take on human subjectivity in relation to the interplay of agents and agency which revolve around V.I.K.I. At the molar scale of signification, the A.I. extends her perceptual field both by her gaze - as a distributed system of surveillance, and by her voice - as configured by the machine-code that controls her hegemonic realm, extensions made possible by her link with the distributed network of NS5 robot- 
bodies. Her agency in the subjective realm of inter-being relations is distributed by her robotic agents. Her subjectivity emerges only in relation to the other subject positions in play: for Spooner, V.I.K.I. thwarts the detective's intent to both solve a murder and correct the "control" problem; for Sonny, V.I.K.I.'s NS5s are trying to kill him and his friends; for Dr. Calvin, V.I.K.I. - who has distorted her command system and mandate, escaped the governing limits of the 3 Laws, and demonstrated a criminal intent to murder humans - is in need of deprogramming, reboot, shut-down or destruction. And, for the NS4s, V.I.K.I. is responsible for their disposal and replacement by the NS5 series, a process that denies any use, labour, or human value of the NS4s.

For distinctions among third order simulacra, other code-based A.I. join V.I.K.I. by their anthropomorphized features at the molar level and a-signifying components, at the molecular. An outside example is viewed in The Resident Evil (2002) film franchise, where again, the controlling A.I. is visible only as a gestalt of bits on a screen. In this sense any cinematic figure, human or robot, is comprised of bits of code, either as genetic DNA or by machine language. The potential for such 2-dimensional figures to register as embodied with human values depends entirely on their assigned function within a particular field of operations. And, with this observation, a mixed semiotics suggest the means to better understand how the robots, as simulations, are distributed in space - that in turn reveals the operational context for the partial and embodied figures of A.I. who pass the Touring test.

Mapping the realm of robotic labours and their usage, the second-order NS4s are clearly connected with the domestic spaces of the home, and with the pedestrian realm of the postmodern city. The NS4s, who become refugees, were originally command coded at the USR robotic factory, and then, distributed to homes as domestics under the local commands of the resident householder. Similarly, the third order simulants as the NS5s, like their predecessors, were encoded initially at the factory, but their intended distribution to homes as the improved domestics is ruptured by the threat Spooner, Calvin and Sonny pose to expose the truth about V.I.K.I. and her NS5s. We see the new NS5s released from their delivery vehicles, but their realm of operations is city-wide, taking command codes only from their controlling A.I. With this centralized mode of control, the part-signs of command bytes flow throughout the urban environment, leaving the pedestrian realm of the NS4s to inform a vast urban distributed network dominated locally by the NS5s, and centrally by V.I.K.I. As a third-order social system, the collective labours of the NS5s figure representationally in a form of micro-politics unbounded by the urban landscape, as we see the pending threat to Sonny crawling up the walls, leaping from roofs, and destroying the urban facades, a far cry from the NS4s' orderly pedestrian behaviours.

Salient features of embodiment are only evident at the molar level of signification, as a gestalt of the a-signifying part-signs or signals. V.I.K.I.'s operational realm spans the distributed network of her NS5s with "her" centralized control hub housed in USR corporate headquarters. But only at the central command hub sitting atop the vast mainframe can we note human features of embodiment. As mentioned earlier, it is the face and voice of the actress that 
register as representational signs of human embodiment. Delimited to the corporate mainframe, V.I.K.I. takes on a maternal image within a specific singular location as the particularized place of the A.I.'s centralized executive functions. However, her body is distributed throughout the urban realm as con-figured in multiple bodies of the NS5s.

\section{Simulated Embodiment: A Mixed Conclusion}

Within a third order of simulation, Baudrillard's anti-semiotics can be seen as a springboard to other post-structuralist theories, such as by Lyotard, or Guattari and Deleuze, who approach semiosis as mixed: combining both signifying with asignifying sign systems. Such linkages are well identified by Gary Genosko, not only in his Critical Semiotics (2016), but in his earlier study of Felix Guattari's glossematic theory of mixed semiotics (Genosko, 1998, pp. 175-190). The premise here is that - at the molecular level of organization - both signifying and asignifying functions interpenetrate to trace a possible diagrammatic path for a shift from a structuralist semiotic model to a post-structuralist mimetic model of signification that is suggested by the works of Walter Benjamin. The two robotic series of $I$, Robot set up this transition from a discursive order of interpretation to a more figurative one, as is more appropriate to the postmodern visual sensorium of social communication and meaning-making. In light of the present pursuit to understand how the cinematic configuration of robot relations can demonstrate a mixed semiotics, a creative human dimension - rather than a closed machinic system - helps us to reconfigure a semiotic to a more figurative mimetic model of social interpretation.

In the essay "Bodies-Cities," Elizabeth Grosz treats embodiment in terms of corporeality, that, "can be seen as the material condition of subjectivity" (Grosz, 1995, p. 381). As depicted in the cinema, embodiment can be seen to register in three interrelated systems of representation: as the affective behavior of a figure with human-like characteristics, as embodied figures who are distributed throughout the urban terminus, and in the dynamic movement of bodies throughout human space. As to the first instance, Scott Bukatman enlists the televisual body as the ultimate mode of terminal identity. As he argues, "the ultimate embodiment (or dis-embodiment) of terminal identity is the electronically enhanced simulation of a human" (Bukatman, 1993, p. 253). Yet while Bukatman treats the virtual body of electronic space - both cinematic and cybernetic - as embodied, the figure is as an object-body only. Bukatman argues that the virtual figure is:

...literally objectified; everything is written upon its surface. In the era of terminal identity, the body has become a machine, a machine that no longer exists in dichotomous opposition to the "natural" and unmediated existence of the subject. (1993, p. 244)

Writing on the role of the body in science fiction, Bukatman defers to the phenomenological model of Merleau-Ponty, to whom he credits the notion that "the body becomes the site of exploration, a site in which the implications of 
postmodern dissolution are inscribed and hypostatized" (1993, p. 259). If the body is the medium that "permits a consciousness of the world," than even the televisual modes of bodies moving in space register as potential figures of embodiment.

Grosz further links the material body with the city, when she writes that there are, "mutually constitutive and mutually defining relations between corporeality and the metropolis" (Grosz, 1995, p. 382). Only in the urban metropolis can the exterior of a body be constructed. "What needs to be shown is how the body is psychically, socially, sexually and representationally produced" (Grosz, 1995, p. 381). For Grosz, the psychic constitution of the robot is produced by the function of the figure in relation to the urban environment, as we saw, for example, in the distinctive relations that separate the placid NS4s from the rabid NS5s. The distinctive embodiment of each robot series can be traced back to their figure as bodily signs, which, for Lyotard, are of two types: the intense and significational (Genosko, 2016, p. 138). The film's narrative supplies the representational significance of the two robotic series, while the intensity of their movements through space helps to define how the different functions manifest as embodied objects in the city. And yet, as in I, Robot, we see Sonny at peace, in anger, with desire and with fear. He may be a cinematic object, but he is also a simulated subject informed by embodied traces of a male actor, as well.

The potential for subjectivity of simulated robot bodies cannot be easily determined by their narrative function as representative organs of a system alone. Genosko highlights the theories of Felix Guattari as offering the clearest potential for the seeming paradox of an object who can be embodied as a subject, or - at the least - with the potential for subjectivity. At the molecular scale of signification, Guattari suggests that even part- or particle-signs carry features of subjective embodiment. Reframing Lyotard's intense and significational sign types, Guattari distinguishes between the affective and the representational. As a critique of Baudrillard's dis-embodied model of anti-semiotics, Guattari's glossematics acknowledges that all part-signs also function in the constitution of affective and sensory experience. For, it is only in the innovative molecular recombination of part-signs that we can hold out a potential for new molar modes of embodiment as desire or subjectivity. Both Lyotard and Guattari then promote a continuum of intensities and of reconfigurations along the molecular - molar scales as a kind of semiotic micro-politics that engages both signifying and a-signifying sign types in parallel and in series.

Last, the role of bodies moving in space can demonstrate a further need for a mixed semiotics to understand signs of embodiment in our postmodern third order of simulation. In I, Robot, both Spooner and Sonny demonstrate how embodiment depends upon bodies moving in space. We find ourselves in the self-driving car with Spooner as he enters the future city. We are kinetically linked with Spooner when he is physically attacked, first by the demolition robot, when the symbolic domestic home is destroyed. Spooner's tumbling through the domestic dwelling during its demotion is akin to a thrill ride at the fair. And, on the covered freeway too, we viscerally experience Spooner's body as the vehicle cavorts, jerks, spins and rolls. And again, but in a larger urban context, we experience the kinesthetic acrobatics of the cinematic body when the NS5s pursue the detective and Dr. 
Calvin in mortal combat at the top of USR headquarters. In each of the three social configurations, the spectator's sympathy with the protagonist is made possible in large part by a combination of both the a-signifying moments of deconstruction alongside signifying moments of representation, as figured by the object body.

But it is in the embodiment of Sonny that the three means of simulated embodiment, by body's function, by body's positioning in a domestic or urban setting, and the movement of bodies through the terminal space, challenge the object-hood of the human-like figure on the screen. Consider key moments in the coming to consciousness of Sonny, whereby the screen object manifests a range of affective intensities, grounded by the intensities of visceral movements through space. Picture Sonny being interrogated with Spooner at one end and Sonny at the other end of the large table, a scene that ends with Sonny's slamming his hands down, leaving the table dented as a physical manifestation of the robot's affective behavior. Or when Sonny is found to still be in the room where the murder took place, he bursts out of his hiding place with a rolling flight through the air, over and above the heads of Spooner and Dr. Calvin. Or, when Sonny smashes through the wall to escape both the USR NS5s and detective Spooner. We see the wall before as complete and after as physically damaged. Or, when Sonny lands on the concrete from his jump out of the building, and we see the indents in the ground from his body's landing. Such movements, with supporting alterations to the immediate environment, tend towards the representation of not an object, but a body as partial subject with affective motivations and interior transformations of his consciousness. Subjectivity then figures in the traces of movement always established by a physical movement in space and by an emotional dramatization of some scene of danger, desire, etc.

In conclusion, we have examined how the object body can simulate subjectivity, both by physical movements with dynamic intensity and by interpersonal exchange in the symbolic order of the representational cinema. Yet, as in the live theatre, where sympathy is only made possible by two mutually constitutive referents, with the human cipher as protagonist - alongside the object body to whom the cipher refers, both are necessary for the spectator to follow the story, and to come to care about a synthetic being - as a subject - as is evident in I, Robot. Only by a mixed semiotics, does it become possible to reconfigure the Other as part-sign and object body into a molar realm of symbolic representation of subjects with a history, a memory, a dreaming consciousness, a coming to subject-hood, and a wide range of affective intensities to support and constitute the simulation of subjectivity in science fiction.

\section{A Closing: Becoming Embodiment, Identification and Mimesis}

Exemplary configurations of human qualities of embodiment register not only in the film, as an embodiment of the actor's work, but in the receptive labours of the engaged spectator. Such labours of attentive engagement make a more embodied realm of cinematic reception possible in modes of psychic identification as proposed by both J. Butler (1990) and J. Lacan (1995). For Lacan, traces of embodiment arise via the gaze and in the experiential enjoyment of the spectator. 
Only in the act of seeing, as the material cause of enjoyment - as a mode of jouissance or pleasure, can we discern the requisite intersubjectivity of identifications embodied within the self-Other co-figuration. ${ }^{5}$ Seeing how one person's body enjoys a part of the Other's body, or how pleasure depends upon our attention to intersubjective relations among multiple bodies, makes our reception of embodiment possible as outlined by Lacan.

But it is in Judith Butler's feminist revision of Lacan that the specific nature of any single body gains qualities of sensual apperception as embodied. Butler uses the term "psychic mimesis" to analyze the intersubjective relations in shared identifications, such as in our experience of watching film, noting three salient features. For the first two, it is in our identification with emergent human-like feelings of the advanced robot Sonny, where Butler would call attention to embodiment as that which informs an erotic style, and a coding of gender in the figure's performance of identity. Sonny's gender may be assumed to be masculine, by voice and frame, but unlike Data of "Star Trek: The Next Generation" - who is fully equipped with functioning male sexual parts, Sonny appears more as an asexual machine, supposedly lacking in desire and the means to reproduce. Yet, in Sonny's energetic style, "he" figures on the continuum from calmly contemplative or as considerate and compliant to a super-charged machinic force, powerful, precise, willful, and capable of incredible feats of acrobatics, running - almost flying - to land in perfect balance, not unlike an Olympian athlete.

Yet again, it is in his bodily movements through space whereby we, as observers, identify with him. But we identify only to the degree that we recognize our own capacities in the difference between our average pedestrian abilities and his additional extra-super human prowess. We may leap with him, in sympathy, but "he" surpasses human skills by extreme movements both in flight to escape arrest and in mortal combat with the NS5s. Far from an erotic style, Sonny embodies a super-human abnormal range of feats of strength, precision and endurance. And, while V.I.K.I. is tacitly feminine, with a female face and voice, Sonny reflects a masculine body, easily associated with a heroic agency in his proactive physical acts, particularly in his masterful abilities to disable his opponents, to outpace his antagonists and to win in every scene of combat.

Butler's third quality of psychic identification requires a co-existence of both desire and of identification. Unlike the "dividuated" NS5s, Sonny emerges as a distinct individual, with a sympathetic desire to be liked, and to be acknowledged as a being by his nemesis, detective Spooner. Again, Sonny's dream scenario functions as evidence of a capacity for identification, notably when his dream (con-)figures Spooner as the savior of the NS4s. But it is only in the recognition scene, when Spooner finally shakes Sonny's hand, as a friend, and as mutually respected individual beings, that we come to feel a co-existence of identification with desire. Sonny has projected his desire to be regarded as a being, into the hands of Spooner, and we are moved by the embodiment of two bodies as equals

${ }^{5}$ On traces of embodiment in Lacan, see his exegesis of objet a (1995, pp. 4-5, 23-25, 29, 49, 62-64). 
who make shared physical contact to confirm a handshake as an agreement between two friends.

And yet, both Butler and Lacan view embodiment only within a cognitivist or psychic dimension of interpersonal relations. Fredric Jameson suggests how embodiment rests in the evident change of a body into a second figuration. As an emblem of the NS5s, Sonny shares an identical body-form with his predecessors, with but one small difference: all the NS5s have a red light within, while Sonny's is blue. The molar difference is evident between the relatively lumpy NS4s and the more streamlined body-forms of the NS5s. But Sonny is distinguished from his kingdom by a subtle color variation, as if it is a personal preference or at the least as an individualizing factor. Jameson, however, is not so concerned about the form or shape of the body, as with its conditional relationship to the past where a body functions as a medium of loss (1991, pp. 68, 156). Jameson argues for a three-fold mediation which is met by the enhanced robot's embodied figure, as a medium or agent who can experience loss. First, Sonny registers with specificity - he has a name, and second, with distinctiveness - in regard to the other robotic machines, both NS4s and 5s. Third, Sonny figures in the context of a social institution, by his labour use value, by his unique circumstances as unwilling murderer, and by the fact of his dream consciousness, as a harbinger of change for the obsolete NS4s.

By his embodiment of the above three mediations in relation to the changing body, Sonny also figures in the film, with an exemplary status and privilege, in terms of loss. Jameson again poses three features of this loss of privilege: a displacement of time (1991, p. 156), a dialectical mediation (p. 157), and a spatial utopia wherein the transformation of social relations is viewed as a projection onto both a particularized place and a human-like body (p. 160). The dream image of the fragmented bridge, for example, represents a displacement in time where the space of the dream registers between two times, both pre-modern and postmodern. We see the loss of a privileged position in human society, as the NS4s huddle among the box-cars in a transportation limbo, awaiting deportation. Sonny, as medium, stands in for the loss of a modern use value, a privilege that the NS4s had held, a privilege that is dialectically conflicted by the usurping NS5s, and a privilege that the dreaming individual Sonny has internalized. Yet, even Jameson's model of embodiment as depicted here reflects a modernist consciousness, and only takes on a postmodern context by being a cinematic simulation. Where Sonny's dream imaginary has been taken hostage, imprisoned as a simulation for the film viewer's imaginary, the mode of embodiment remains a mourning for a past modernist utopia. In the postmodern cinematic context, the robots may take human form, but they remain a third-order computerized simulation and only vicariously can they restore, or stand in for, the semblance of another human subject.

Considering the mode of embodiment suggested by Deleuze and Guattari, we must be satisfied to see the desire of a robot, not as in a fantasy or in a dream, but always in relation to an assemblage, "a collective or multiplicity" (1972/1983, p. 256). And further, as distinguished in Anti-Oedipus, "desire only emerges [by] the rupture of a previous equilibrium" (1972/1983, p. 255). For, while the desiring robot may be an agent, it is not a person, and the relations among its multiple 
iterations are not the same as intersubjective relationships. Only by the one-on-one relationship established between Sonny and Spooner can we distinguish how desire can emerge among partial objects. Sonny's relationship with Spooner sets him apart from all the other robot series, and his coming to consciousness breaks through as a co-existence of shared subject positions, which, however partial, rupture the prior equilibrium defined by the 3 Laws of Robotics, and as challenged by the NS5s.

Scott Bukatman takes this machinic imaginary further when he writes that, as terminal flesh, the body in science fiction can only ever be an "immanent subject" (Bukatman, 1993, p. 264). Where the body is literally objectified as a machine, science fiction denies the body, "displacing its attention to the telematic viewscreen" (Bukatman, 1993, p. 264). Yet, a significant revision to Bukatman's view of embodiment is evident when he calls attention to the view of cyberpunk author Bruce Sterling who has worked closely with William Gibson. For Sterling, "by contrast, technology is visceral," and as we inscribe human-like qualities on to robots - as when we identify with them as if they had subjective features, the body only emerges as a subject "in a state of kinetic, sensory pleasure" (as quoted by Bukatman, 1993, p. 238). And from Sterling's viewpoint, the spectator identifies with the machine to the degree that we take pleasure in its kinetic sensory movements and actions, as we have noted about Sonny's superhuman athletic capacities that register for us as kinetic pleasures.

The limitations of a signifying model of signs become readily apparent when we consider the machinic kinetics in terms of human appreciation for sensuosity. Mark Henson proposes that only by a shift to mimetics, as Walter Benjamin argued for an irreducible embodied experiential domain, can the cinematic/ machinic configuration register in a post-linguistic dimension (Hansen, 2000, p. 231). Benjamin's German notion of Erlebnis as lived bodily experience is what makes human sensuality possible, and what leads him to propose a non-sensuous form of semiosis that is figural, and mimetic or imitative in nature. Only by "a practical embodied basis - to our context with the material world" can we identify with the simulated signs of technological reproduction (Hansen, 2000, p. 232). The embodied experiential domain is absent from much post-structuralist thought, and most obviously lacking in the theories of simulacra and telemorphosis of Baudrillard. For our cinematic audience to be able to humanize the robot, whether as partial object or as fragmented subject, or in some hybrid of the two, we must sublimate the desire for mastery over the semiotic signification, and - under the experiential conditions of the post-linguistic imagistic world turn - demand a shift from semiotic signification to mimetic embodiment in order to realize the historicized subject.

\section{Acknowledgements}

No part of this article has been printed before, and there are no outstanding submissions to any other publisher with this content. 


\section{References}

Adorno, T. W. (1997). Aesthetic theory (R. Hullot-Kentor, Trans., \& Intro.). Minneapolis: University of Minnesota Press. (Original work published 1970)

Baudrillard, J. (1981). For a critique of the political economy of the sign (C. Levin, Trans.). St. Louis: Telos Press Publishing. Reprinted in Jean Baudrillard: Selected writings (2nd ed., pp. 60-100). M. Poster (Ed.). Stanford: Stanford University Press, 2001). (Original work published 1972)

Baudrillard, J. (1983). Simulations (P. Foss, P. Patton, \& P. Beitchman, Trans.). New York, USA: Semiotext(e). Reprinted in Jean Baudrillard: Selected writings (2nd ed., pp. 169-187). M. Poster (Ed.). Stanford: Stanford University Press, 2001. (Original work published 1981)

Baudrillard, J. (1993). Symbolic exchange and death (I. H. Grant, Trans.). Thousand Oaks: Sage Publications. (Original work published 1976)

Baudrillard, J. (1996). The system of objects (J. Benedict, Trans.). London, New York: Verso. Reprinted in Jean Baudrillard: Selected writings (2nd ed., pp. 13-31). M. Poster (Ed.). Stanford: Stanford University Press, 2001. (Original work published 1968)

Baudrillard, J. (2010). The agony of power (A. Hodges, Trans.). Los Angeles: Semiotext(e). (Original work published 2006)

Baudrillard, J. (2012). Telemorphosis (D. S. Burk, Trans.). Minneapolis: Univocal.

Behind the scenes: The making of I, Robot. (2004). Retrieved from <youtube.com/ watch? $\mathrm{v}=\mathrm{t} 1 \mathrm{Dw} 2 \mathrm{c} 2 \mathrm{eRR} 4>$.

Benjamin, W. (1986). On the mimetic faculty. In P. Demetz (Ed.), E. Jephcott (Trans.), Reflections: Essays, aphorisms, autobiographical writings (pp. 333-336). New York: Schocken Books. (Original work published 1933)

Bukatman, S. (1993). Terminal identity: The virtual subject in postmodern science fiction. Durham: Duke University Press.

Butler, J. (1990). Gender trouble. New York: Routledge.

Danto, A. C. (1994). Embodied meanings: Critical essays and aesthetic meditations. New York: HarperCollins.

Deleuze, G. \& Guattari, F. (1983). Anti-Oedipus: Capitalism and schizophrenia (R. Hurley, M. Seem, \& H. R. Lane, Trans.). Minneapolis: University of Minnesota Press. (Original work published 1972)

Ex Machina. (2015). (Director Alex Garland) Universal Pictures Inter'l, Film4, DNA Films, IAC Films. Release date 24 April 2015, USA.

Flieger, J. A. (2000). Becoming-Woman: Deleuze, Schreber and molecular identification. In I. Buchanan, \& C. Colebrook (Eds.), Deleuze and feminist theory (pp. 38-63). Edinburgh: Edinburgh University Press.

Genosko, G. (1998). Guattari's schizoanalytic semiotics: Mixing Hjelmslev and Peirce. In E. Kaufman, \& K. J. Heller (Eds.), Deleuze \& Guattari: New mappings in politics, philosophy, and culture (pp. 175-190). Minneapolis: University of Minnesota Press.

Genosko, G. (2016). Critical semiotics: Theory, from information to affect. New York: Bloomsbury.

Grosz, E. (1995). (Ed.). Bodies-Cities. Space, time and perversion: Essays on the politics of the body. London: Routledge. Reprinted in Feminist theory and the body: A reader (pp. 381-387). J. Price \& M. Shildrick (Eds.). New York: Routledge, 1999.

Guattari, F. (1984). Molecular revolution: Psychiatry and politics (R. Sheed, Trans.). New York: Penguin. (Original work published 1977) 
Guattari, F. (2011). The machinic unconscious: Essays in schizoanalysis (T. Adkins, Trans.). Los Angeles: Semiotext(e)/Smart Art.

Hansen, M. (2000). Embodying technesis: Technology beyond writing. Ann Arbor: University of Michigan Press.

Hayles, N. K. (1991). The borders of madness. Science Fiction Studies, 18(3), 321-323.

I, Robot. (2004). (Director Alex Proyas) Twentieth Century Fox, Mediastream Vierte Film $\mathrm{GmbH} \&$ Co. Vermarktungs KG, and Davis Entertainment.

Jameson, F. (1991). Postmodernism; or, the cultural logic of late capitalism. Durham NC: Duke University Press.

Jameson, F. (2005). Archeologies of the future: The desire called utopia and other science fictions. New York: Verso.

Kroker, A. \& Kroker, M. (1987). Thesis on the disappearing body in the hyper-modern condition. In A. Kroker, \& M. Kroker (Eds.), Body invaders: Panic sex in America (pp. 20-34). New York: St. Martin's Press.

Lacan, J. (1995). Reading seminar XI: Lacan's four fundamental concepts of psychoanalysis. R. Feldstein, B. Fink, \& M. Jaanus (Eds.). New York: State University of New York.

Lazzarato, M. (2014). Signs and machines: Capitalism and the production of subjectivity (J. D. Jordan, Trans.). South Pasadena: Semiotext(e).

McQueen, S. (2016). Deleuze and Baudrillard: From cyberpunk to biopunk. Edinburgh: Edinburgh University Press.

McNally, D. (2011). Monsters of the market: Zombies, vampires and global capitalism. Boston: Brill.

Merleau-Ponty, M. (1962). Phenomenology of perception (1962) (C. Smith, Trans.). London: Routledge \& Kegan Paul. (Original work published 1945)

Morris, M. (1984). Room 101 or a few worst things in the world. In A. Frankovits (Eds.), Seduced and abandoned: The Baudrillard scene (pp. 91-117). Sydney: Stonemoss Services.

Norris, C. (1990). What's wrong with postmodernism? Critical theory and the ends of philosophy. London: Harvester Wheatsheaf.

Resident evil. (2002). (Director Paul Anderson), Sony Pictures Entertainment, Screen Gems, Constantin Film, New Legacy, Davis Films and Impact Pictures.

Rojek, C., \& Turner, B. S. (1993). Introduction: Regret Baudrillard? In C. Rojek, \& B. S. Turner (Eds.), Forget Baudrillard? (pp. ix-xviii). London: Routledge.

Sobchack, V. (1991). Baudrillard's obscenity. Science Fiction Studies, 18(3), 327-329.

Solo: A star wars story. (2018). (Director Ron Howard) Lucasfilm, Walt Disney Pictures, Allison Shearmur Productions, Imagine Entertainment.

Sterling, B. (1986). Preface. In B. Sterling (Ed.), Mirrorshades: The cyberpunk anthology (pp. vii-xiv). New York: Arbor House.

The stepford wives. (1975). (Director Bryan Forbes) Palomar Pictures International, Fadsin Cinema Associates, US distributor Columbia Pictures.

The wizard of Oz. (1939). (Director: Victor Fleming). Warner Bros.

Woods, A. (2011). The sublime object of psychiatry: Schizophrenia in clinical and cultural theory. Oxford: Oxford University Press. 
